\title{
Comparison of stereochemical structures of cholesterol from different sources by HPLC
}

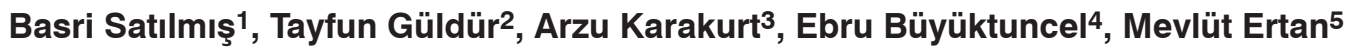

\begin{abstract}
It is known that only one stereoisomeric form, nat-cholesterol, naturally occurs. Nat-cholesterol and its enantiomer, ent-cholesterol, sometimes show enantiospecific interactions with biological molecules. If cholesterol is naturally found only one form, then the question of "why does cholesterol show an enantiomeric selectivity?" arises. For this purpose, stereoisomer analysis of cholesterol obtained from porcine liver and wool wax were carried out with three different high performance liquid chromatography (HPLC) systems including reversed-phase, reversed-phase with different cyclodextrins as a mobile phase modifier, and chiral. Results from HPLC analysis of both cholesterol samples by permethylated $\gamma$-cyclodextrin and amylose tris-(3,5-dimethylphenylcarbamate) chiral columns showed that there was no stereoisomer of cholesterol present. However reversed-phase HPLC analysis of cholesterol samples from porcine liver carried out with various cyclodextrins as mobile phase modifiers presented a peak which was not observed in the analysis of cholesterol samples from wool wax. On the other hand, different storage conditions of cholesterol samples and addition of cyclodextrins as mobile phase modifiers produced almost identical alterations in chromatograms of fresh samples by reversed-phase HPLC. This could be attributed to catalytic properties of cyclodextrins. Cyclodextrins may not be suitable as a mobile phase modifier in the stereoisomer analysis of cholesterol with high performance liquid chromatography.
\end{abstract}

KEY WORDS: Cholesterol, stereoisomer, chromatography, chiral, cyclodextrin

\section{INTRODUCTION}

Cholesterol plays important roles in many functions of cells. Presence of cholesterol in cells in right amount and place is necessary for membrane structure and function, signal transduction and as a result, for human health (1). Additionally, cholesterol metabolites e.g. steroids and bile acids have important biological roles including signal transduction as well as lipid solubilization (2). On the other hand, unbalanced cholesterol distribution has been found to be related to many disorders including atherosclerosis, coronary artery disease, hypertension, Alzheimer, diabetes as well as cancer (1).

Cholesterol has tetracyclic cyclopentanoperhydrophenanthrene skeleton with a hydroxyl group attached to carbon 3 and a side chain at carbon 17. Cholesterol consists of polar head group and apolar hydrocarbon body conferring the molecule amphipathic property. Its fused tetracyclic structure and eight chiral centers make 256 stereoisomers of cholesterol molecule possible (3).

It has been reported that cholesterol occurs naturally in only one stereoisomeric form, i.e. natcholesterol, owing to the nature of enzymatic reactions of steroid synthesis (1). However, it is known that enantiospecific cellular proteins take part in cholesterol absorption in hamsters (4). Additionally, ent-cholesterol, enantiomer of cholesterol, and nat-cholesterol exhibit enantiomeric interaction with cholesterol oxidase but not with epidermal growth factor (1). Then the question arises "if cholesterol naturally occurs in only one form, why interaction with cholesterol exhibit an enantiomeric selectivity? To this end, stereoisomeric homogenity of cholesterol from porcine liver and wool wax has been investigated using HPLC method with C18 column with and without cyclodextrins as mobile phase modifier and two different chiral columns.

\section{AFFILIATIONS}

1̇̇nönü University, Faculty of Pharmacy, Department of Biochemistry, Malatya, Turkey

2̇̉nönü University, Faculty of Medicine, Department of Medical Biochemistry, Malatya, Turkey

3Inönü University, Faculty of Pharmacy, Department of Pharmaceutical Chemistry, Malatya, Turkey

4İnönü University, Faculty of Pharmacy, Department of Analytical Chemistry, Malatya, Turkey 5 Hacettepe University, Faculty of Pharmacy,

Department of Pharmaceutical Chemistry, Ankara, Turkey

\section{CORRESPONDENCE}

Tayfun Güldür

E-mail:

tayfun.guldur@inonu.edu.tr

Received:

13.04.2012

Revision:

12.07.2012

Accepted:

16.07.2012 
Analysis with permethylated $\gamma$-cyclodextrin $(\gamma-C D)$, and amylose tris-(3,5-dimethylphenylcarbamate) (ADMPC) chiral columns showed that no cholesterol stereoisomer is present. However, HPLC analysis using C18 column with cyclodextrins as mobile phase modifier, a peak was detected in cholesterol from porcine liver which was not found in cholesterol from wool wax.

\section{EXPERIMENTAL Materials}

All chemicals and solvents were of analytical grade. Cholesterol obtained from porcine liver (C-PL) was purchased from Sigma (Saint Louis, Missouri, USA) and cholesterol obtained from wool wax (C-WW) from Acros Organics (NewJersey, USA). HPLC grade isopropanol from Merck KGaA (Darmstadt, Germany) and acetonitrile were purchased from JT Baker (Deventer, Holland). Cyclodextrins; a-cyclodextrin, $\beta$-cyclodextrin, $\quad \beta$-methylcyclodextrin, $\beta$-hydroxypropylcyclodextrin, $\quad \gamma$-cyclodextrin, $\gamma$-hydroxypropylcyclodextrin were purchased from WackerChemie AG (Burghausen, Germany). Ultrapure water used for mobile phase was generated by water purification system from Human Corporation (Seoul, Korea).

\section{Instrumentation}

An Agilent 1100 System (Agilent Technologies, Palo Alto, CA, USA) comprising quaternary solvent delivery system, an on-line degasser, a manual injection, a column temperature controller and DAD detector was used for the analysis. Separations were carried out using C18 column, 250x4,6 mm, $5 \mu \mathrm{m}$ particle size (ACE, Aberdeen, Scotland), permethylated gamma-cyclodextrin ( $\gamma$-CD), 200x4,6 mm, $5 \mu \mathrm{m}$ particle size or, amylose tris-(3,5-dimethylphenylcarbamate) (ADMPC) chiral columns, 250x4,6 mm, $5 \mu \mathrm{m}$ particle size (Macherey Nagel, Düren, Germany).

\section{Reversed-phase HPLC conditions}

Chromatographic separations with C18 column were carried out by isocratic system with mobile phase consisting of isopropanol:acetonitrile:water (60:30:10, v:v:v). The mobile phase was prepared daily and filtered through $0,45 \mu \mathrm{m}$ Milipore membrane and degassed for 15 minute in an ultrasonic bath prior to use. Mobile phase was delivered to the system at a flow rate of $1 \mathrm{~mL} / \mathrm{min}$ and the $\mathrm{UV}$ detector was set at $210 \mathrm{~nm}(5)$.

\section{Reversed-phase HPLC conditions with cyclodextrin as a chiral agent in mobile phase}

All the chromatographic parameters were the same as described in reversed-phase HPLC conditions. $0.01 \%$ various cyclodextrins (w/v) was added to mobile phase as a chiral agent.

\section{Chiral HPLC conditions}

Chromatographic separations with both chiral columns were carried out by isocratic system. Mobile phase composition was isopropanol:acetonitrile:water (60:30:10, v:v:v) for $\gamma$-CD column (5) whereas hexane:isopropanol (90:10, v:v) was used for ADMPC column (6). Mobile phase was delivered through the system at a flow rate of $1 \mathrm{~mL} / \mathrm{min}$ and the UV detector was set at $210 \mathrm{~nm}$ for both columns. Mobile phase preparation was the same as described in reversed-phase HPLC.

\section{Sample Preparations}

C-PL and C-WW were dissolved in mobil phase of HPLC column used at a concentration of $200 \mathrm{ppm}$.

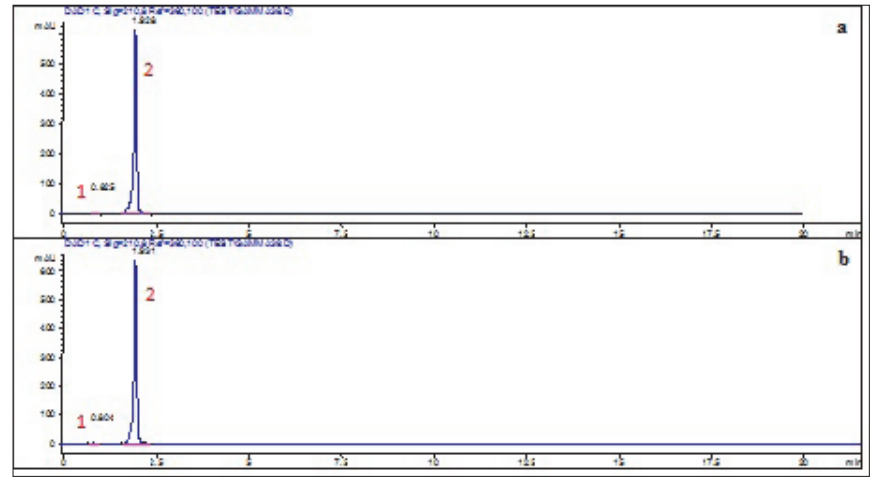

FIGURE 1. Chromatograms obtained with $\gamma-\mathrm{CD}$ chiral column from analysis of freshly prepared samples of C-PL (a) and C-WW (b).

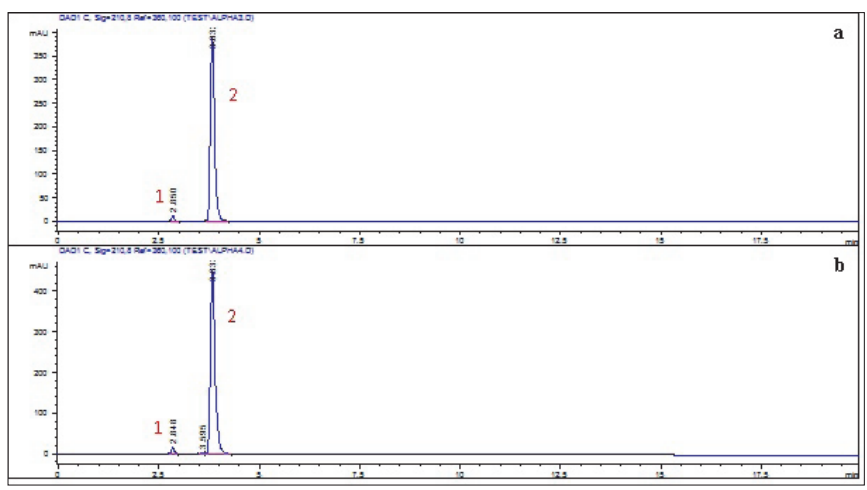

FIGURE 2. Chromatograms obtained with ADMPC chiral column from analysis of freshly prepared samples of C-PL (a), C-WW (b).

In order to investigate and compare the effects of storage conditions on C-PL and C-WW, freshly prepared samples were divided into three aliquots and subjected to either UV or different storage temperatures.

C-PL and C-WW samples dissolved in mobil phase at a concentration of 200 ppm were exposed to UV light in an open petri dish at room temperature for 3 hours. An aliquot of C-PL or C-WW samples were kept in a capped volumetric flask at room temperature for one month. Remaining aliquots were kept in a capped volumetric flask at $+4{ }^{\circ} \mathrm{C}$ for 1 month.

\section{RESULTS}

\section{Investigation of cholesterol stereoisomers with chiral columns}

Chromatograms from analysis of freshly prepared samples of C-PL and C-WW by $\gamma_{-C D}$ chiral column were shown in Figure $1 \mathrm{a}$ and $1 \mathrm{~b}$. Results from both samples show that cholesterol peaks had same retention time and there was no different stereoisomer present. Void volume of $\mathrm{\gamma}$-CD chiral column was calculated as $1.76 \mathrm{~mL}$, and small peaks eluted in void volume were considered to be impurities. Considering the retention time of cholesterol peak it can be seen that cholesterol exhibits a poor interaction with $\gamma$-CD.

When the stereoisomer homogenities of C-PL and C-WW were investigated with ADMPC chiral column, similar results were obtained. Retention time of cholesterol peaks for both samples and impurity were identical. Peaks eluted in void volume were also similar (Figure 2a and 2b). 


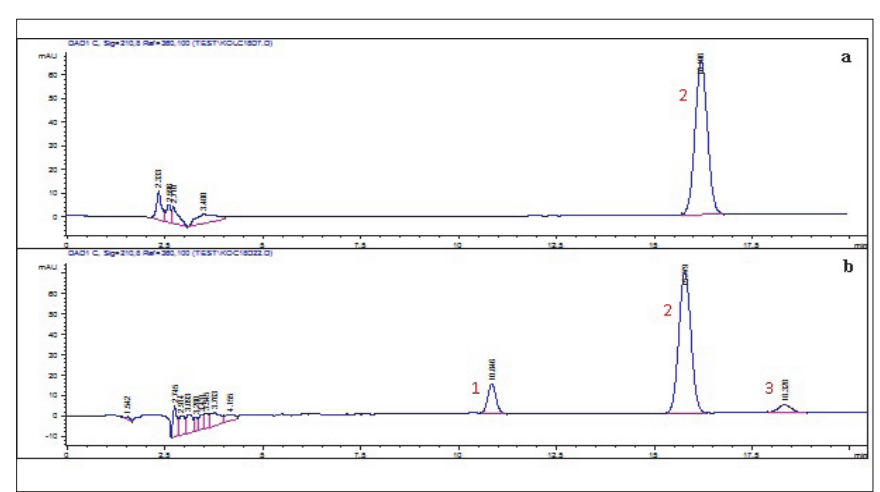

FIGURE 3. Chromatograms of C-PL samples by reversed-phase HPLC analysis (a) without, (b) with the addition of $\gamma$ - hydroxypropyl cyclodextrin.

\section{Investigation of cholesterol stereoisomers with cyclodextrins as mobile phase modifier agents}

Various cyclodextrins were added to mobile phase of reversedphase HPLC with C-18 column. To this end, 0.01\% (w/v) a-cyclodextrin, $\quad \beta$-cyclodextrin, $\beta$-methylcyclodextrin, $\beta$-hydroxypropylcyclodextrin, $\quad \gamma$-cyclodextrin or $\gamma$-hydroxypropyl cyclodextrin were added to mobile phase for the analysis of C-PL and C-WW samples with reversed-phase HPLC. Among cyclodextrins only $\gamma$-hydroxypropyl cyclodextrin results were shown in Figure 3 and 4.

Retention times (RT) of cholesterol peaks (peak 2) varied between 15,612-17,599 depends on type of cyclodextrin added as mobile phase modifier. For C-PL sample, peak 1 (RT 10,84612,796 ) with shorter retention time than peak 2 , and peak 3 (RT 18,312-21,547) with longer retention time than peak 2 were determined, but somewhat peak 3 was not determined in the analysis with $\gamma$-cyclodextrin. For C-WW sample, unlike C-PL sample, peak 1 was determined by reversed-phase HPLC both with and without cyclodextrin addition as mobile phase modifier (Figure 4) (chromatograms of other cyclodextrins were not shown).

Reversed-phase HPLC analysis carried out by adding cyclodextrin to mobile phase for C-PL and C-WW, retention times of peaks 2 and peaks 3 overlap for all types of cyclodextrins. However, retention time of peak 1 was calculated as $11,44 \pm 0,5$ for C-PL sample, whereas 12,12 $\pm 0,41$ for C-WW sample for 6 different cyclodextrins. Elution time of peak 1 for C-PL sample was $0,69 \pm 0,13 \mathrm{~min}$. shorter than $\mathrm{C}-\mathrm{WW}$ sample and peak height was found to be approximately two times higher than that of C-WW sample.

According to results of reversed-phase HPLC analysis, number of peaks related with impurities between 2,3-3,5 min. retention time increased by adding cyclodextrins to mobile phase. Initial number of impurity peaks between 1,5-4,2 retention times was 3 or 4 , whereas after addition of cyclodextrins to mobile phase number of peaks increased to 8 or 9 (Figure 3 and 4 ). In order to define these peaks whether probable stereoisomer or decomposition products of cholesterol, reversedphase HPLC analysis of C-PL and C-WW samples kept under different storage conditions were conducted.

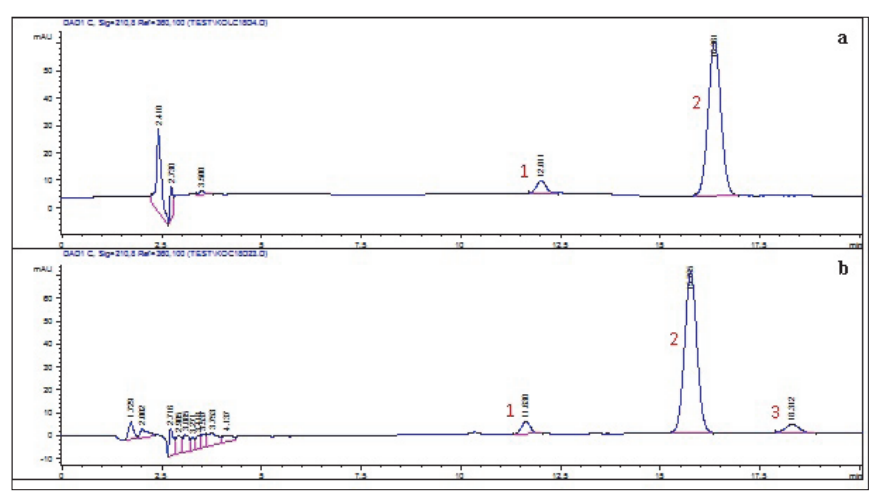

FIGURE 4. Chromatograms of C-WW sample by reversed-phase HPLC analysis (a) without, (b) with the addition of $\gamma$ - hydroxypropyl cyclodextrin.

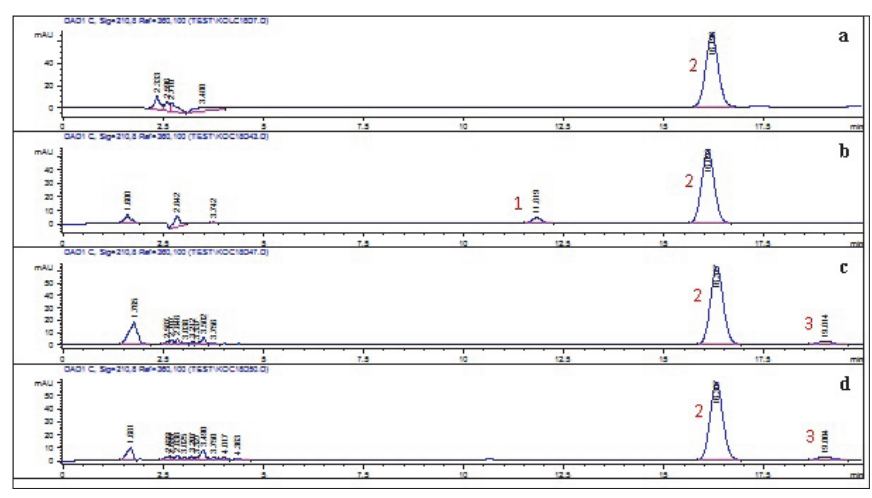

FIGURE 5. Chromatograms of reversed-phase HPLC analysis of C-PL samples under different conditions. Freshly prepared (a), exposed to UV light (b), kept at room temperature (c), kept at $+4^{\circ} \mathrm{C}(\mathrm{d})$.

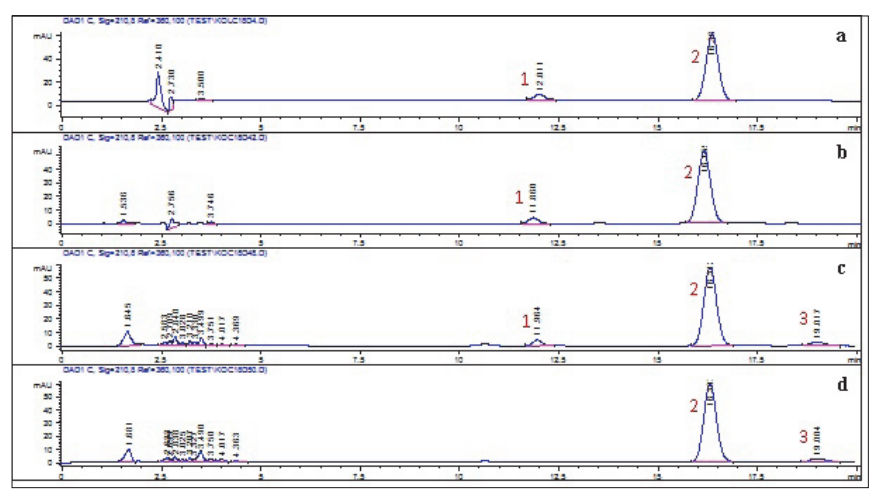

FIGURE 6. Chromatograms of reversed-phase HPLC analysis of C-WW samples under different conditions. Freshly prepared (a), exposed to UV light (b), kept at room temperature (c), kept at $+4^{\circ} \mathrm{C}(\mathrm{d})$.

\section{Investigation of stereoisomers of samples kept under different storage conditions}

C-PL ve C-WW samples were dissolved in mobile phase, kept under UV light or room temperature, or at $+4{ }^{\circ} \mathrm{C}$, and reversedphase HPLC chromatogram of these samples were compared with that of freshly prepared samples (Figure 5 and 6).

For both cholesterols analysis, new small peaks with the retention time ranging between 1,6 to 4,4 and peak 3 appeared in samples 
kept at room temperature and $+4^{\circ} \mathrm{C}$ for a month. Although peak 1 was present in C-WW sample, this peak also appeared after exposition to UV light. Peak 2 has the same retention time for both cholesterol samples. As a result, chromatograms of reversedphase HPLC analysis of samples kept at room temperature and at $+4{ }^{\circ} \mathrm{C}$ bear resemblance with chromatograms of reversed-phase HPLC analysis of freshly prepared cholesterol samples carried out by adding cyclodextrins to mobile phase. Retention times of peak 1 and peak 3 overlapped with retention times of peak 1 and peak 3 of analysis with cyclodextrins of all types.

\section{DISCUSSION}

Cholesterol possesses many structural and physiological functions in living organisms i.e. taking part in membrane structure, synthesis of bile acids and steroid hormones. Involvement of high plasma cholesterol level in pathogenesis of atherosclerosis and high death rate in humans from coronary artery disease attract considerable research interests to the molecule.

Eight chiral centers of a cholesterol molecule render 256 cholesterol stereoisomers possible. However, cholesterol occurs naturally in only one stereoisomeric form, nat-cholesterol. On the other hand, the fact that enantiospecific cellular proteins take part in cholesterol absorption warrants investigations of cholesterol stereoisomers from different sources. To this end, cholesterol stereoisomers of C-WW and C-PL were analyzed by chiral columns. Results obtained from chiral HPLC analysis of C-WW and C-PL showed that cholesterol peaks from both samples had same retention time and that there was no cholesterol stereoisomer present. It was reported by Anderson that little differences existed between physical properties of cholesterol obtained from different sources (7). Although in 1929 it was reported that new cholesterol stereoisomer was found by Montignie, this data however was not verified in following studies (8).

General approach used in separation of enantiomers with HPLC is to use chiral stationary phases or to employ $\mathrm{C} 18$ columns with mobile phase modifier agents like cyclodextrins. Formation of transient diastereisomers with different physical properties as a result of interaction between chiral agent and ligand constitutes the basis of enantiomeric separation by HPLC (9). As an alternative way to separation by chiral columns, reversed phase HPLC analysis were conducted for both cholesterol samples by adding various cyclodextrins to mobile phase. Retention times of peak 2 and 3 of both samples overlapped well for all types of cyclodextrins used. However, retention time for peak 1 of C-PL sample was found to be 0,69 min shorter than that of C-WW sample. It is tempting to speculate that two cholesterol samples from different sources may not be homogenous in terms of stereoisomerism. However, our data at present are not enough to support such conclusion. It is obvious that in order to define these peaks in more detail, thorough analysis by LC-MS and preparative HPLC are required.

Results of reversed-phase HPLC analysis with cyclodextrins showed that in the first five minutes of chromatogram considerable increases in number of small peaks occured compared to reversed-phase HPLC analysis without addition of cyclodextrins. It has been reported that cholesterol in acetonitrile/isopropanol solvent system could be converted to oxysterols by enzymatic or non-enzymatic means (10). Therefore, in order to find out whether or not these small peaks are possible stereoisomers or degradation products of cholesterol, reversed-phase HPLC analysis of cholesterol samples kept under different conditions were carried out. First five min of chromatograms of stored cholesterol samples by HPLC also exhibited small peaks in paralel with those of HPLC analysis with the addition of cyclodextrins. Since esterase, phosphatase, epoxidase and oxidase activity of cyclodextrins and cyclodextrin derivatives have been reported (11), it is possible to conclude therefore that addition of cyclodextrins to mobile phase might chemically alter cholesterol structure and therefore should be used with caution in stereoisomeric analysis of cholesterol.

Natural cholesterol occurs in only one stereoisomeric form, on the other hand enantiospecific proteins mediate cholesterol absorption, moreover, nat-cholesterol and ent-cholesterol, enantiomeric form of nat-cholesterol, have different interaction characteristics with these proteins. However, our data do not clearly indicate the presence of cholesterol stereoisomers in cholesterol samples from wool wax and porcine liver. Whether or not cholesterol from other sources contain stereoisomers is currently unknown. An answer to the question "why interaction with cholesterol displays an enantiomeric selectivity" remains to be solved.

\section{Farklı kaynaklardan elde edilen kolesterolün stereokimyasal yapılarının HPLC ile karşılaştırılması}

ÖZET: Kolesterol molekülünün doğada sadece bir stereoizomerik formda, nat-kolesterol, bulunduğu bilinmektedir. Nat-kolesterol ve enantiomeri olan ent-kolesterol, biyolojik moleküllerle bazen enantiospesifik etkileşimler göstermektedir. Bu durumda, kolesterol doğada bir formda bulunuyorsa "kolesterol neden enantiomerik seçicilik göstermektedir?" sorusu ortaya çıkmaktadır. Bu amaçla, domuz karaciğeri ve koyun yün yağından elde edilen kolesterolün stereokimyasal analizleri, ters-faz, mobil faz modifiye edici ajan olarak farklı siklodekstrinlerin kullanıldığı ters-faz ve kiral' den oluşan üç farklı HPLC metodu ile gerçekleştirilmiştir. Her iki kolesterol örneğinin, permetillenmiş $\gamma$-siklodekstrin ve amiloz tris-(3,5-dimetilfenilkarbamat) kiral kolonlar ile yapılan HPLC analizlerinde kolesterol stereoizomeri bulunmamaktadır. Bununla birlikte, domuz karaciğerinden elde edilen kolesterol örneğinin çeşitli siklodekstrinlerin mobil faz modifiye edici olarak kullanıldığı ters-faz HPLC analizlerinde belirlenen bir pik, koyun yün yağından elde edilen kolesterol örneklerinin analizinde gözlenmemektedir. Öte yandan, farklı bekletme koşullarındaki kolesterol örneklerinin ters-faz HPLC analizleri ile yeni hazırlanmış kolesterol örneklerinin siklodekstrinlerin mobil faza eklendiği ters-faz HPLC analizleri sonucunda, kromatogramlarda hemen hemen birbirine eş değişiklikler gözlenmektedir. Bu durum siklodekstrinlerin katalitik özelliklerine dayandırılabilir. Bu nedenle, kolesterolün HPLC ile stereoizomer analizinde mobil faz modifiye edici olarak siklodekstrinlerin kullanılması uygun olmayabilir.

ANAHTAR SÖZCÜKLER: kolesterol, stereoizomer, kromatografi, kiral, siklodekstrin 


\section{REFERENCES}

1. Westover EJ, Covey DF. The Enantiomer of Cholesterol. J Membrane Biol 2004; 202: 61-72.

2. Ikonen E. Cellular cholesterol trafficking and compartmentalization. Nature Rev Mol Cell Biol 2008; 9: 125-38.

3. Sarker SD, Nahar L. Chemistry for pharmacy students: general, organic and natural product chemistry. John Wiley and Sons Ltd: England, 2007.

4. Westover EJ, Lin X, Riehl TE, Ma L, Stenson WF, Covey DF, Ostlund RE. Rapid transient absorption and biliary secretion of enantiomeric cholesterol in hamsters. J Lipid Res 2006; 47: 2374-81.

5. Duncan IW, Culbreth PH, Burtis CA. Determination of free, total and esterified cholesterol by high-performance liquid chromatography. J Chromatogr B Biomed Sci Appl 1979; 162: 281-92.

6. Kummer M, Palme HJ, Werner G. Resolution of enantiomeric steroids by high performance liquid chromatography on chiral stationary phases. J Chromatogr A 1996; 749: 61-8.
7. Anderson RJ. Properties of cholesterol obtained from different sources. J Biol Chem 1927; 71: 407-18.

8. Kaishio Y, Gardner JA. Note on Montignie's isomer of cholesterol, and the effect of heat on cholesterol. Biochem J 1930; 24: 1047-50.

9. Han SM. Direct enantiomeric separations by high performance liquid chromatography using cyclodextrins. Biomed Chromatogr 1997; 11: 259-71.

10. Hosokawa $Y$, Hakamata $H$, Murakami $T$, Aoyagi $S$, Kuroda S, Mimaki Y, Ito A, Morosawa S, Kusu F. Electrochemical oxidation of cholesterol in acetonitrile leads to the formation of cholesta-4,6-dien-3-one. Electrochim Acta 2009; 54: 6412-6.

11. Bjerre J, Rousseau $C$, Marinescu L, Bols M. Artificial enzymes, "Chemzymes": current state and perspectives. Appl Microbiol Biotechnol 2008; 81: 1-11. 